\title{
GEOSTRATEGY OF ECONOMIC SPACES: Innovation and Change in Latin America Territorial Administration
}

\author{
Euripedes Falcão Vieira, Marcelo Milano Falcão Vieira*
}

\begin{abstract}
In this essay we analyze the geostrategy of economic spaces in the sphere of new links in the global economy, placing Latin America in the scenario of the new world order. The geostrategic dimension of economic spaces includes spatial redefinitions as a result of new global strategies of the major transnational corporations. This is, therefore, of a space-time configuration of scenarios in the articulation between the importance of the place, action site, and expression of power. Territorial administration adopts new outlines, sharing and is linked to the logistics of market interests. In the new configuration of interests of global economics, the spatial barriers are set aside and global places are created, representing fragmentations of territorialized space. Territorialization of global productive spaces represents deterritorialization of national spaces. Forms of power and influence of power radiate from them in all directions. Power and administration of territory in the large complex economic and political organisms - regional blocks - confront each member's historic reality, the inequalities of the rates of development, culture and social levels.

These realities are hard to harmonize and eventually categorize hegemonic centers of power and a national fringe of dependence. Global geostrategy, therefore, takes over, redefines and reorders productive circulation spaces, establishing new relations of power and administration of territories. Historically, Latin America continued to depend heavily on the economic order established by the colonizing countries and this dependence gradually shifted to the world financial supremacies. This dependence intensified the indebtedness process that today characterizes the so-called market of foreign debts, with significant reflections on the internal social order.
\end{abstract}

Keywords: global geostrategy, power and transterritorial administration, cyberspace-time, innovation.

* - Euripedes Falcão Vieira. E-mail: euripedesfalcao@terra.com.br

Address: Rua General Portinho, 35/903. CEP: 96200-210. Rio Grande - RS, Brazil.

- Marcelo Milano FalcãoVieira. E-mail: Marcelo.Vieira@fgv.br

Address: FGV/EBAPE, Praia de Botafogo, 190 - Botafogo - sala 530 - Botafogo. CEP: 22253-900. Rio de Janeiro - RJ, Brazil. 


\section{Introduction}

This paper is a study of the geostrategy of economic spaces in the sphere of new links in the global economy. In particular, it refers to Latin America in the context of transterritorial production. In each Latin American country's territory global economic spaces are created, connected to the networks of transterritorial multipolar production. These spaces characterize global productive fragmentations and from them spread out forms of power and influence of power, adopting new concepts of territorial administration. The territorial strategies in a context of multipolar production are relevant to the relations and operationalizations established between the different market dimensions. The geostrategic dimension of economic spaces includes spatial redefinitions as a result of new global strategies of the major transnational corporations. This is, therefore, of a space-time configuration of scenarios in the articulation between the importance of the place, action site, and expression of power. At today's technological stage commanded by the speed of virtual reality, the time-space paradigm is the expression of a changing world, in which distances no longer matter and the centers and bases of actions form the logical connections in the act of producing, commanding and exercising power and influence of power.

Territorial administration adopts new outlines, sharing and is linked to the logistics of market interests. In the new configuration of interests of global economics, the spatial barriers are put aside and global places are created, representing fragmentations of territorialized space. Territorialization of global productive spaces represents deterritorialization of national spaces (Vieira \& Vieira, 2003).The geography of national, transnational, regional and continental places is a time-space of physical and virtual realities. Forms of power and influence of power radiate from them in all directions. Power and administration of territory in the large complex economic and political organisms regional blocks - confront each member's historic reality, the inequalities of the rates of development, culture and social levels. These realities are hard to harmonize and eventually categorize hegemonic centers of power and a national fringe of dependence. Global geostrategy, therefore, takes over, redefines and reorders productive circulation spaces, establishing new relations of power and administration of territories. Consequently, action and power materialize around a physical object that is the global-place, transforming it into a global geographic object in which economic practices are confined and transterritorial power expressed.

Multilateral agreements in the new context intend to assure benefits and comparative edges between countries and groups of countries. Nevertheless, Bauman (1999:36) refers to a recent multilateral investment agreement, "which to all extents and purposes ties the hands of national governments and unties those of extraterritorial companies". But this is a reality of the new transterritorial economic time-space dimension, indicating the main landmark of weakening the sovereignty.

Since the 1970's, cybernetic time-space was introduced by the advances of microelectronic technology and changed the standards of production, organization and administration of territory. Knowledge and information took command of economic life, which was the basis for somehow conditioning customs, procedures and tendencies. The place grows in important when setting up large productive and particularly high-tech complexes in different parts of the world. Capitalism now becomes global inasmuch as it produces, assembles, distributes and is organized in networks all over the world. Large production is now global; consumer goods have various components produced in various global-places of the world. It is now a fast and global economy. Information and decisions flow instantly between the centers and seat of economic action. Change and innovation are key words in the new world scenario, defining the post-modern paradigm.

New models of territorial administration, primarily those of sharing between the public and private power, evolve with the new territorial strategies of production. The question of power and territorial administration will only be understood in the light of this new reality. Nation States have lost power to the global economy and their sovereignties have suffered several scratches. Major economic blocs and numerous international organizations that control the financial sector and world trade form global governance to which nation States on the capitalist fringe are obliged to endure in the context of historic dependence.

Latin America is a heavily dependent continentality, fragmented into transterritorial spaces, bilateral agreements and politically rather than economically based alliances, projecting uncertainties and losses. Latin American uncertainties dominate the $\mathrm{Pa}$ cific and Atlantic countries. The agreements of the Andean Pact and Association of Caribbean States lost their impetus. On one hand, through the bilateral agreements of Chile, Peru, Ecuador and Bolivia with NAFTA and EU; while seeking alliance agreements with Mercosur.Venezuela, given its power of petroleum, is a free agent, forcing a basically political inclusion in Mercosur. The countries in the Association of Caribbean States extend their relations with NAFTA, projecting a union of the North and Central American and Caribbean countries, as if in a, speculatively, progressive political and economic formulation of FTAA, advancing in parts, in less conflicting blocs. 


\section{Economic Space: global geostrategy}

The society at the dawn of the third millennium is surely the most contradictory ever. Fast technological innovations, political transformations with widespread repercussion, the new economy, and virtual highways form the large spectrum of the new era. Everything happens in the shorter time-space, in a world without boundaries, of the global and local, of networks and techniques. It is the society of the rich, luxury and comfort, but also the society of poverty, misery and hunger. The so-called information era (Castells, 1999) is of an unequaled luster in the apparatus of techniques and intelligence, but also the era of social inequalities, social exclusion, and poor quality of life for millions of people.

The view of a new productive time-space configuration, global action strategies and macro-regional links define today's geostrategy of economic spaces, global power and transterritorial administration.

The geostrategy of global economic spaces is a time-space configuration in logistic territorialities of interest to the major world corporations. On the other hand, region-States, with their own parliaments, common currency and global strategies will dominate the means of production, circulation and consumption in the forthcoming years. They will also, of course, be the centers of global power radiating out through local and regional multipolarities. The radical changes and impacts of the new global order on peripheral nation-States are sources of uncertainties for future scenarios.

Geostrategy of economic spaces, from a global viewpoint, shapes new regional categories beyond traditional geographic benchmarks; they are scenarios of territorial postmodernism. As Boisier (1996) pointed out, it is no longer an autarchic territoriality but interactive, multipolar in production, in the objectives to ensure consumer markets, mutual cooperation and reinforcement of national identities. The organization, redefinition and administration of the global productive territory - global-places - evidence the importance of places. They are economic spaces with another formulation; a fragmented productive space, interactive, multipolarized in feedstock, components and assembly lines to, however, assure the global character.

In times of a new international economic order, places now play a leading role in defining global strategies. Places are disputed because their strategic position, benefits offered, installed logistics and infrastructure permit productive and circulatory operations in the globalization process efficiently and at lower costs. Within the new categorization of place, local-places and global-places, and corresponding powers within them, may be indicated. For a better understanding of the two categories it is necessary to take a quick glance at the conceptual analysis.

The local-place is the space of historic heritage. The perception of past constructed realities is projected from it, upgraded according to economic rates and renewed with cultural progress. The local-place is the keystone of organized territory (Vieira \& Vieira, 2002). Demographic, economic and cultural processes are of a historic nature and belong to the context of economic and social formation of the inserted region. The global-place is the definition of space as a result of the globalizing drive of the economy. It may be part of the local-place where the global ratio deterritorializes the productive space, in the sense of separating the center of the action from the seat of the action, according to Santos (1996). Hence, the global-place is the seat of the action, where productive and circulatory practices are operationalized; the center of the action, however, may be very remote, virtualized in operations of command.Administration of the territory, in the new dimension of places, depends on the forces acting upon it. The intensity of the forces lies in the immediate ratio of power emanating from the interests at stake. The greater the power of transnational corporations, the more influence over the appropriation and administration of the territory.

The reality of power and administration of productive territories in Latin America gives each nation-State the status of an object rather than being included, in fact, as an active agent, that is, subject to a global process. Because of further misunderstandings, fragmentations of general interest, and, for the most part, disputes of regional hegemony, South American supranational spaces are particularly diverging rather than converging. This reality undermines agreements with other already consolidated economic blocs and the design of a powerful Latin American macro-region, or at least South American conformation.

\section{Flows and New Forms of Organization and re- definirion of Territory}

Civilizations have been organized and developed through demand flow systems and decisions. Over the years the scope and form of constructed space varied, also changing the nature of the flows. Nowadays, economic practices have followed the process of enhancement and technological progress, gradually increasing the speed of knowledge and information. The evolution of technology influenced social and economic revolutions at different times in history, defining and redefining present-day aspects. New technologies have always caused changes and the latter caused restructuring, passing through the times of each modernity.

The technological revolution launched by microelectronics, glo- 
bal economy, internationalization of the nation-State and the emerging powerful region-States according to logistic attributes and the geostrategy of economic spaces. The lowering of spatial barriers, the global-places, transnational regions, crossflows of production and circulation of goods in shared consumer regions form the spectrum of what is called territorial postmodernism (transterritoriality). The organization and functioning of territories shared by multilateral agreements, giving rise to transnational regions of interest between countries economic blocs and mega-blocs - constitute territorial macrocategories. As a result, region-States are formed wherein principles of organization and functionality are established to meet reciprocal interests. Adopting contractual procedures implies establishing a specific political and juridical order to ensure the reinforcement of the region-States.

Multicentrality of economic flows more closely identifies the current status of capitalism, the principal premises of which are: high-tech, information and knowledge, and global markets. All those factors reveal a historic situation of convergence and, at the same time, of fragmentation. They converge for the new spatial forms of investment in units of partial production, representing technological fragmentations that will form flows to spaces of erection. There is a global interconnection between end production, production of components, assembly lines, consumer markets, information, know-how, new technologies and the power and influence of power of a transterritorial nature.

The spaces of flows soon ceased to be national. The time-space for strategies of production, circulation and consumption is now transterritorial, with no barriers or frontiers and, very often, no sovereignty. The company alone decides on where, how and how much to invest in production or complementary units. The proximity of large consumer blocs guarantees market control, at lower costs in contexts of privileged production. The loss of national productive identity is a risk now under assessment. The fear is that the time of sustained development is wasted, which may be very costly to the nation. Certainly, in the process of opening up to global insertion, no due consideration was given to the fundamental principle that the dialectics of globalization is the dialects of transterritorial power. Almost boundless power of capital and from it, as an immediate consequence, the powers of manipulating markets, weakening social structures, being subject to imposed values and meanings. Capitalism is an economic system focusing on growth. Development adds social content and depends on public policies. With the growth in transterritorial economic power, the political power of national identities, on the other hand, diminishes.

Global flows are more intense without the former national restrictions, demonstrating that the lowering of spatial barriers is a reality. In regions with large production and consumer flows, the emerging major power is belongs to the transnational corporations. A global logic of transterritorial realities is sanctioned, overwhelming national realities. Denationalizing the economy assumed proportions that went beyond the boundaries of the minimum control of both natural and economically generated national wealth. Furtado (2000) defends a new economic procedure in which the priorities are to fortify home markets, invest heavily in training skilled labor, reform the rural structure, be less dependent on outside financing and more concerned with social problems, and to return to planning policies. In Brazil the major national development plans that permitted building the power, telecommunication, transportation and regional development systems were replaced by denationalization policies and dependence. Foreign administration of the strategic segments of the Brazilian economy will, as Furtado (2000) says, lead to an increase in the ongoing outward flow of internal resources.

\section{Characterization and Reordering places in the global economy}

Place, action and power are the new components in organizing, redefining and administrating territories in the sphere of the global economy. The analysis of these components is the theme included in the considerations of territorial postmodernism. Analysis of spatial categories of the global economic strategies - the place, region, macro-region - fixes the geometry of transterritoriality. Territorialization of global productive spaces characterizes the global-places that may represent deterritorialization of national spaces from the viewpoint of operationalizing the production and circulation of goods. In those action areas of the major transnational corporations, different forms of influence are expressed on territorial administration.

Fragmentation of space (socioeconomic) defines the emerging reality of the economic globalization process: the place where global productive practices are adopted. Links between the action of producing and expressing power in territorial administration are established, therefore, in the constructed space or are being redefined.

The nature of the place, its productive representativity, inclusion in global strategies, connection to worldwide networks and internationalization of the flows represent current time-space economic dimension. Territorial postmodernism bursts spatial barriers (national), redefines and reorders the concept of region, producing transterritorial places in the global economy. The transformation of scenarios where the importance of the place, place of economic action and expression of power combine, based on logistic attributes, adopts the transterritorial ge- 
ostrategic category as a result of global and regional economic integration (Vieira \& Vieira, 2000).

Regionalization, in economic terms, has a broader meaning than the classic geographic region. Economic integration in blocs is found in an economic region whose boundaries and interests go beyond the traditional geographic region. Recently (2003) Japan and ASEAN launched a major regional project to create the East Asia Community; a short time later (2004) six Asian nations laid the foundations for a free trade zone and widespread geographic coverage headed by India and Thailand. The EU, ASEAN and FTAA will extend economic regionalism to new spatial scales.

The agreements between NAFTA and Central American and Caribbean countries may mean a move toward FTAA. The group in Latin communities less sensitive to geostrategic disputes, mostly due to the historic dependence, has been a successful effort. In the Mercosur sphere, new projects are being adopted, but an alliance spectrum configured by surrealist political impulses rather than of regional rationality.

Economic regionalization, as it is understood, is, in its multiple forms - multilateral, associative, communities, blocs, zonings -, in fact, a conceptual transit, since its boundaries are undefined and its interests can vary in time. Boudeville (196I), in the paper "Economic Spaces" forecast the present time when he said that "geographic space is one dimension of a more complex space: economic space".

The new economic regions and places therein appear as an important element in the (re)order, administration and integration of the territories in worldwide networks. The adoption of transterritorial strategies furthers political actions and economic pressures that determine redefinitions and new orders, creating spatialities specific to production, concentration and turnover of economic goods. From peripheral territories to the hegemonic centers of the global economy, the negotiations for opening up privileged paces to the practice of competitive strategies by major transnational corporations set the new scene of global economy. The new world strategies form new relations between companies and governments of the countries where they are implemented. In practice, governments are restricted to fulfilling the interests of transnational companies, granting them benefits to make them competitive on the international market.

The time-space paradigm is, therefore, the new basis of fast global economy. Fast production, fast transportation and fast consumption offer through appropriate technologies a tight compression of time-space. Distances are now a social product whose range and costs vary depending on the velocity adopted to overcome them, according to Bauman (1998).

The national spaces of interest to production and consumption are re-organized and included in the global traffic of the economy.Appropriation, construction or transformation of the space can characterize territorially determined forms based on the objects and actions developed therein. In the concept, space has a dialectic meaning leading to the understanding of the turnover and dynamics of actions and objects. Logistic spatiality, defined in central places of economic action, produces the dialectics of fragmented spaces. Space dialectics is also time dialectics, since all actions leading to the production of space have a sense of time. Accelerations of time in economic processes lead to the elimination of space, configuring the concept of space-time compression (Harvey, 1989).

\section{Global Ratio, Power and Influence of Power on Territory}

The global economy introduced new expressions of power. Bauman (1999: 80) believes that "a remarkable trend of our time is the growing gap between power and politics: true power, that can determine the extent of the practical options, flows and, thanks to the ever diminishing restraints on its mobility, has become virtually global, or rather, extraterritorial". The global economic ratio introduces a form of power that transcends politics; it is a power that determines territoriality of action with only secondary or complementary participation of national political representativity, particularly on the dependent fringe. In postmodernity, power has become an expression of linked and suggested strategic virtualities and commands, assuming the immaterial reality projected in cyberspace-time.

The dialectics of political/economic power almost always conditions social life. Conducts and forms of behavior exist, almost as an imposition, from images and symbolic signs. Symbolic power, according to Bourdieu (2001: 9) "is a power that builds reality". Globalization arrived laden with symbols that moved aside for the arrival of new forms of power, whether through concrete or virtual reality.

Transterritorial global power, the power of cybernetic flow, induced and instantaneous from the centers of economic action undoubtedly configures postmodern reality. As Bauman points out (1998: 77), we live in "a world where capital has no fixed domicile and the financial turnover is largely beyond the control of national governments", and adds that transnational forces that weaken the States are the same as those that exclude them from the terrain of deliberate action, which results in a potentially rational condition of dependence.

Political power is dominated by the "invisible" power introdu- 
ced by globalization. Market forces, the super-forces, evidently exercise power without identification by name. It is the anonymous power that is felt and acts beyond national sovereignties. The new scenario of power is nourished by the fact that the centers of transterritorial values and meanings are commanded by the "invisible" power, as Bauman (1998) suggested.

In the global present, the constructed productive space releases forces of power and influences of power from the dialectics of economic power. Global-places are territorialized nationally for production and deterritorialized for the purpose of flows and expressions of power. If power did not exist, but rather practices of power, as Foucault (1996) says, it could be considered that globalization is responsible for congruent practices and relations of power; power is now something that is wielded, achieved, and that functions, according to the author. Now, if the global economy and information technologies produce a society in network, it is consensual that power is also networking, that is, there is a network of power that flows through the same routes as the networks that create economic relations. In concrete terms, there is latent power in political, economic and social relations whose expression depends on circumstances. Since power is not an actual entity, it becomes an attribute of whatever represents a concrete situation.

The global economy offers another characteristic of power, a result of the multipolarity of centers and seats of economic action: power without a center (Touraine, 1994). The centers of economic action create flows of power through the networks connecting different business interests. In the economic world, power is formed as a relational structure in very complex environments, principally in the cyberspace-time dimension. What flows through the cyberways is a form of power, impersonal and horizontal, rational and without inflexible regulations; this is the distant and at the same time instant virtual power. Power in the global economy is wielded without personal confrontation, without direct determination between people; in fact, it is the information flows that generate practical actions loaded with intrinsic power.

Globalization (even in its abstract formulation) is a comprehensive economic power, indexed, ideological and armed; a real dialectic and imposed power.

Market economies have always behaved dubiously toward the power of the nation-State. Lebrun (1999: 80) recalls: "when it prevails, the market economy needs a power that can maintain the conditions of its natural functioning". The power of the nation-State, the control that it held over national economies, no longer resists the impetus of outside flows, of both capital and of services, technologies and information. National crises are no longer discussed at the domestic level of each country, but with international organizations that submit the granting of loans or debt renegotiation to measures of fiscal adjustment, always involving social restraints. Organizations such as IMF and World Bank emphasize agents instated at the heart of the power of each country in crisis, deciding what to do and how. When a nation-State loses the power to intervene in the economy and maintain control over it, it then only administrates decisions and influences of the global economic power.

Shared power also appears in the global economic spaces. The places seats of global economic action incorporate forms of influence of power reflected in territorial administration. The centers of political power grant global spaces to fragment territories, encouraging articulation in terms of administration of the territory. This means that when circles of power are created in the spatial forms proposed by globalization, each will have its share in the administration of the territory. This link between the global and the local presupposes a concept of shared power among the various legal-administrative categories of constructed economic spaces or those being redefined.

\section{Cyberspace-time, virtual interactivity and the Worldwide Web}

Microelectronic technology, considered unique in the drive for knowledge, foresaw a horizon of social events, time-space configured to the new form of reality: the virtual. Cyberways were created as virtual routes along which symbols, representations of ideas, intentions and information circulate, and everything carried from points, subjectivities and immaterialities. This new world of virtual reality became, particularly after the 1990's, the very image of concrete, objective and material reality of the global economy. Both realities mix and merge, in fact, in a single route of complicity demarcated by cyberspace-time.The demarcation has an expansive sense, since technological advances rapidly broaden the horizons of the economic, social and cultural events of increasingly transitory current events. The thrusts of interactivity in a network system, an interconnecting web of events produced in geostrategic environments of production spaces and flows of demands and decisions move along the highways of cyberspace-time. The organizational field created by information technologies increased the possibilities of interconnecting flows and narrowed distances to virtual points.

There is a perception of disconcerting concrete and virtual reality. It moves from a geostrategic viewpoint of fragmented productive spaces - global-places - to another of the virtual interconnection through information and decision networks. If there is also a territorial strategy for production, and with the same intensity, then there is another for the flows between the 
centers and seats of action. From those two points or nodes of virtual logic subjectivities, others cascade forward to the dimensions of trade and consumption. They are, in fact, two parallel worlds comprising a single comprehensive field, that of economic organizations. Interactivity passes through the two realities, creating between them a complex of relations in which immediate interests of an economic nature are identified and overlap, expressing power and influences over the administration of the territory.

The characterization of cyberspace-time and all implications of a practical nature in today's society commend the understanding of change, innovation and differentiation of behavior guiding the relations of postmodern time. Interactions between the centers and seats of economic action, at various levels and scales of attributions, characterize strategic commands much more than subordination as such. The specification of attributions involves setting strategic activities in motion, through the system of cyberspace interactivity. Power is more implicit and is now an attribute of performance, contrasting with the explicit power of personalized hierarchization. Power becomes an expression of value added to know-how and information of whoever has them.

The worldwide web is a form of interactive expression of power. Cyberspace-time is the immaterial materialization of this new form of power. It is an abstract and subjective form but always a form of power induced by action. Action that flows through cyberways generates suggested power interpreted and valued according to the energy intensity of whatever it carries. In this case, the impersonal prevails, as when oscillatory market behaviors are found against events that benefit them or not.

Cyberspace-time, interactivity and transterritorial webs clearly characterize the new era. The cybernetic era has left the time of modernity behind and begun another, time of postmodernity.

\section{Time of Modernity and Postmodernity}

The 20th century has been particularly marked by events that accelerated scientific and technological innovations and, consequently, changes such as, paradoxically, world wars, the Soviet revolution, and the ensuing ideological confrontation.

The time of the last modernity was that of the industrial society and the social order that it developed. Postmodernity is the new time in the technological domain, restructure of the capitalist system, productive multicentrality, society of knowledge, strategic webs linking up the flows, and in hegemonic and dependent transterritorialities. It is a post-industrial time referring to the profile of industrialists and the whole cultural, economic, political and social context created during an industrial revolution; knowledge and information are now the key focus of the new society.

Postmodernity is a new definition, a new order and dimensioning of the global society, principally since the 1990's. The events that determined the passage of industrial modernity to information postmodernity are factual: the cybernetic revolution, globalized economy, fall of the political-ideological revolutionary model, organizational and administrative changes, transterritorial power, advances in knowledge and information. In this short period of time, the standards and meanings of the modern era established during the long years of the industrial revolution have rapidly been left behind. There have been amazing transformations in society, particularly in the last three decades of the 20th century. The most accurate analysis of the events in the past fifty years clearly shows that postmodernity is not a mental exercise, an unfocused and vague time regarding concrete facts, or even undistinguished on a scale of the group of events indicating modernity. Modernity and postmodernity portray the set of social changes, supported by important signs determining new stages in human evolution. Thus, the cycle of major maritime discoveries crosses over the order of medieval society, giving rise to social movements of change and a new way of thinking. Any modernity, therefore, is nothing but a radical change in the ways of expressing social order and individual and collective capacities, commanded or unleashed by an emblem that becomes a reference in social evolution. The steam engine and computer are emblems of an era that caused radical changes in the evolution of society. The individual being and social being reacted to the innovations with new forms of behavior that did not represent only conformities or adaptations to the natural evolution of technology and thought, but also, much to the contrary, radicalized their own actions as social players. This reality imposed by radicalizing the time of change, and fed with new mental models, establishes the cycles of modernity and postmodernity.

What differentiates the cybernetic era from earlier eras is the immaterial nature of the main objects of economic and organizational life. A world of virtualities now dominates the objectivities and subjectivities of the new reality. Cybernetic reality contrasts with material reality, building cyberspace-time in new languages, symbols and concepts. Thought commands invisible flows, being displaced by only imaginable cyberways, but that, for the new standards and paradigms of the created virtualities, represents concrete images of accepted and countersigned actions. The world of images, symbols and meanings created by advanced technologies generates more wealth in a much shorter time than the long and controversial years of industrial mo- 
dernity. In the next few years, faster change, innovation and behavior will more clearly characterize postmodernity. Other postmodernities will be introduced to the time of new technological, scientific and information modernities.

\section{Conclusion}

The advent of the global economy caused substantial changes in national customs, culture and identities. Knowing how far the global technological-economic phenomenon will go to produce a global society and especially when is unpredictable. Nevertheless, the tendency is for the national economic society to be constantly inserted in the global society, already outlined, incorporating a wide range of globally acceptable and adopted customs, political actions, values, and meanings. The basic issues of power, territory and territoriality are highlighted in the new spectrum.

The question of territory and territoriality was well put by Sassen (1999:100):"an impact of the economic globalization on the territorial jurisdiction or, more theoretically, that of territoriality solely of the nation-State". Sassen raises an important question, which can be seen as a clear perception of the present reality:"we are witnessing incipient processes of denationalization of sovereignty; partial displacement of the sovereignty of the Nation-State". The author also continues (p.I0I): "my hypothesis is that which, while globalization leaves the national territory basically unchanged, it is having pronounced effects on the territoriality solely of the national state, that is, its effects are not so much in the territory itself but in adopting an institutional cocoon of the geographic fact of national territory. Economic globalization implies a set of practices that shake up another set of practices, for example, practices that had constituted the sovereignty of the national State".

National societies increasingly share the idea of the global, a close interaction of the national-global duality, especially when the flows of postmodern life shift through the new dimension of space - cyberspace. The boundaries imposed by industrial modernity on society through the ideological State apparatus are outdated by the new postmodern concepts of economic and social organization. Interaction between the global processes of social action configures an interdependent reality. It is precisely this reality that is one of the most outstanding features of postmodern society, so incomplete, still imperfect and consequently unfair; but global, without a doubt!

The Latin American affirmation in the structural and organizational complex of globalization highlights the way in which each
nation-State participates in the new world economic order. Participating as a subject of global economic action is undoubtedly a competitive edge. Accordingly, however, it is necessary to establish development policies for each nation-State and policies of participation in economic blocs that assure the benefits of production and international exchanges. The share administration of the territory, in this case, is an instrument of national and regional affirmation before the reality of the global economy.

It is essential for Latin America to define its kind of insertion in the global order.The region is traditionally a supplier of primary products, but will be unable to have a strong competitive edge without becoming a reality of knowledge, in other words, characterizing cognitive regionality. To produce know-how and technology depends on formulating internal policies mostly in the educational field.Vieira \&Vieira (2004, p. I77) say that "each country will be the result of its investments in education". Internal policies with such focus have already demonstrated good results and breaking away. Good short-term results and breaking away from the past of merely formal education. In Asia the examples are impressive, with countries such as Japan, China, Korea and India becoming powers of know-how and technology, and added together, characterizing a vast region of knowledge. The leap in this case was primarily of a conceptual nature, that is, how to look at the internal development process from the outside.

Internal development, or endogenous for many, is not only growth as extolled today. It is a project initially focusing on strengthening internal bases, infrastructure, education, health, qualifying the individual and organized collectives, and the rational and sustainable use of natural resources. In fact, it is the harmonious composition between exclusive territorial jurisdiction (internal order) and shared administration when addressing inclusion in macro-regional spaces (external strategic view). Internal development projects create a close identity for the nation-States, offering them conditions to participate as active agents in transnational regional compositions and, consequently, in the overall global economic order.

\section{References}

BAUMAN, Z. (1998) Globalization:The Human Consequences. Oxford: Blackwell Publishers.

BAUMAN, Z. (1999) In Search of Politics. Oxford: Blackwell Publishers.

BOISIER, S. (1996) Modernidad y Territorio. Santiago de Chile. 
Cuadernos del ILPES, 42.

BOURDIEU, P (200I) O Poder Simbólico. Rio de Janeiro: Bertrand Brasil.

BOUDEVILLE, J. R (I96I). Los Espacios Económicos. Buenos Aires: Eudebra.

CASTELLS, M. (1999) A sociedade em rede,Volume I, São Paulo: Paz e Terra.

CASTELLS, Manuel (1995). The Rise of the Network Society. Oxford: Blackwell Publishers.

FOUCAULT, M. (1996) Microfisica do Poder. Rio de Janeiro: Graal.

FURTADO, C. (2000) O Capitalismo Global. São Paulo: Paz e Terra.

HARVEY, D. (1989) The Condition of Postmodernity. Oxford: Blackwell Publishers.

LEBRUN, G. (1999) O que é poder. São Paulo: Brasiliense.

RUSSELL, B. (1938) Power: a New Social Analysis. London: George Allen \& Unwin.

SANTOS, M. (1996) A Natureza do Espaço:Técnica e Tempo, Razão e Emoção. São Paulo: Hucitec.

SASSEN, S. (1999) Território e Territorialidade na Economia Global. In Barroso, J. R. (Org.) Globalização e Identidade Nacional. São Paulo:Atlas.

TOURAINE, A. (1994) Critique de la Modernité. Librarie Paris: Arthème Fayard.

VIEIRA, E. F. \& Vieira, M. M. F. (2002) Geoestratégia dos Espaços Econômicos: o Paradigma Espaço-Tempo na Gestão do Território. In Tânia Fischer (Org.) Gestão do Desenvolvimento e Poderes Locais: Marcos Teóricos e Avaliação. Salvador: Casa da Qualidade.

VIEIRA, E. F. \& Vieira, M. M. F. (2003) Espaços Econômicos, Geoestratégia, Poder e Gestão do Território. Porto Alegre: Sagra-Luzzatto.

VIEIRA, E. F. \& Vieira, M.M.F. (2004) A Dialética da Pós-modernidade: a Sociedade em Transformação. Rio de Janeiro: FGV Editora.

\section{About Authors}

Euripedes Falcão Vieira is Doctor in Geography from Universidad Del Salvador, Buenos Aires, Argentina. Member of the Historic and Geographic Institute of Rio Grande do Sul, in Porto Alegre, Brazil. Current research interests: geostrategy of economic spaces; power and administration of territory; public administration.

Marcelo Milano Falcão Vieira is Ph.D. in Business Studies from the University of Edinburgh, Scotland. Deputy professor of the Brazilian School for Public and Business Administration, Getulio Vargas Foundation (EBAPE/FGV), in Rio de Janeiro, Brazil. His research interests relate to the influence of power and the institutional environment in structuring organizations; formation and structuring of organizational fields; territorial administration. 